\title{
Anorectal malignant melanoma: MRI findings with pathological correlation
}

\author{
Kritika Sharma, ${ }^{1}$ Rajaram Sharma ${ }^{0},{ }^{2,3}$ Tapendra Tiwari, ${ }^{2}$ Saurabh Goyal ${ }^{2}$
}

${ }^{1}$ Department of Radio-diagnosis, Pacific Institute of Medical Sciences, Udaipur, India ${ }^{2}$ Department of Radio-diagnosis, Pacific Institute of Medical Sciences Umarda Campus, Udaipur, India

${ }^{3}$ Department of Radio-diagnosis, Seth GS Medical College and KEM Hospital, Mumbai, India

\section{Correspondence to}

Dr Rajaram Sharma;

hemantgalaria13@gmail.com

Accepted 22 October 2021

Check for updates

(c) BMJ Publishing Group Limited 2021. No commercial re-use. See rights and permissions. Published by BMJ.

To cite: Sharma K, Sharma R Tiwari T, et al. BMJ Case Rep 2021;14:e247421. doi:10.1136/bcr-2021247421

\section{DESCRIPTION}

Anorectal malignant melanoma is a rare entity with a less than 5-year survival rate. Malignant melanoma of the gastrointestinal tract is primarily bloodborne metastases predominantly involving the stomach and small bowel because of its high blood supply. However, very few primary malignant mucosal melanoma cases are reported within the oesophagus and anus, but the rectum is the rarest area of involvement. ${ }^{12}$ Patients, mainly women, typically present with regional symptoms like anal pruritus, blood in the stool or rectal pain in the fifth or sixth decade of life and because of these regional symptoms and histological variability, this entity may get confused with haemorrhoids, adenocarcinoma, polyps or lymphoma.

Moreover, even when some tumorous lesion is found in the rectum or anal canal, differentiation of primary anorectal melanoma from other neoplastic lesions is not easy because of the lack of common imaging findings. Anal melanoma is staged, focusing on the locoregional and distant spread. Stage I is a local disease only, Stage II comprises local disease with increased thickness and ulcerations, Stage III includes the involvement of regional lymph nodes and Stage IV has distant metastatic disease. ${ }^{3}{ }^{4}$ MRI is the best modality for this condition as its tissue characterisation and soft-tissue resolution is far superior to those of CT scan. High-signal intensity on T1-weighted (T1W) imaging and mixed-signal intensity on T2-weighted (T2W) imaging are classically described MRI features. However, that is not a universal rule. ${ }^{5}$ Here we present a case of amelanocytic melanoma with very atypical MRI findings.

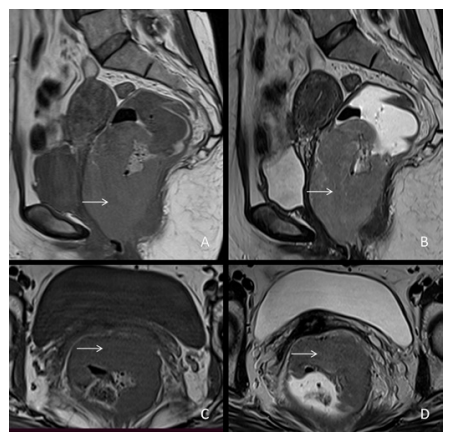

Figure 1 Magnetic resonance sagittal plane images T1 sequence $(A)$ and $T 2$ sequence $(B)$ shows asymmetric polypoidal wall thickening involving mid and lower rectum (white arrow). Axial plane images T1 sequence (C) and $T 2$ sequence (D) depicts the same lesion arising from anterior and lateral walls (white arrow). Note that the lesion appears hypointense on T1W and hyperintense on T2W images.

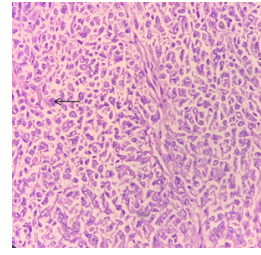

Figure 2 40X histopathology section reveals turous arranged sheets of cells, with prominent navicular nuclei (black arrow) and a moderate amount of suggesting a diagnosis of malignant melanoma.

A 54-year-old woman came to our hospital with complaints of pain during defecation and blood in stool for 2 months. She was a non-smoker with an unremarkable medical history. On per rectum examination, the surgeon felt a mass-like lesion in the rectum, and he could see a large polypoidal ulcerated lesion on proctoscopy. The patient was advised for an MRI pelvis, which revealed asymmetric, eccentric wall thickening involving anterior and lateral walls of the rectum (maximum wall thickness of $38 \mathrm{~mm}$ ) in a $9 \mathrm{~cm}$ long segment. The lesion was extending into the perirectal fat, lower uterine segment and the cervix anteriorly. The lesion was extending into the mesorectal fascias on the left side with a few large $(>1 \mathrm{~cm})$ perirectal deposits. On MRI, the mass is characterised as iso to hypointense on T1W/T2W images (figure 1A-D) and hyperintense on Short Tau Inversion Recovery (STIR) images. These findings favoured an aggressive malignant mass lesion. As this lesion was hypointense on T1W images, diagnosis of melanoma was not kept in the differential, however to our surprise; the histopathology examination illustrated turous arranged sheets have prominent navicular nuclei and a moderate amount of cytoplasm suggestive of amelonocytic malignant melanoma (figure 2). Due to its high recurrence rate and systemic dissemination, abdominoperineal resection (APR) or wide local excision (WLE) was considered for making the patient disease free for some

\section{Patient's perspective}

I was facing difficulty in maintaining bowel habits and feeling very irritated because of continuous pain in the abdomen. After coming to the hospital, doctors did a biopsy and informed me about this grave disease. Life is getting difficult day by day for me. However, I am very thankful to the hospital staff for making a definite diagnosis and helping me further. 


\section{Learning points}

- Anorectal melanoma is a highly malignant condition with a poor prognosis.

- The possibility of anorectal melanoma remains in the patient with bulky intraluminal rectal mass, which manifests T1 hypointensity. Therefore, histopathological examination is essential for diagnosis.

time. Because of the high morbidity associated with APR, the patient preferred WLE, and presently she is on chemotherapy.

Contributors KS and RS contributed to the planning, conduct, reporting, conception and design, acquisition of data, or analysis and interpretation of data. TT and SG contributed to the acquisition of data and interpretation of data.

Funding The authors have not declared a specific grant for this research from any funding agency in the public, commercial or not-for-profit sectors.
Competing interests None declared.

Patient consent for publication Consent obtained directly from patient(s).

Provenance and peer review Not commissioned; externally peer reviewed.

\section{ORCID iD}

Rajaram Sharma http://orcid.org/0000-0003-1126-5875

\section{REFERENCES}

1 Meguerditchian A-N, Meterissian SH, Dunn KB. Anorectal melanoma: diagnosis and treatment. Dis Colon Rectum 2011;54:638-44.

2 Chang AE, Karnell LH, Menck HR. The National cancer data base report on cutaneous and noncutaneous melanoma: a summary of 84,836 cases from the past decade. The American College of surgeons Commission on cancer and the American cancer Society. Cancer 1998;83:1664-78.

3 Singer M, Mutch M. Anal melanoma. Clin Colon Rectal Surg 2006;19:078-87.

4 Row D, Weiser MR. Anorectal melanoma. Clin Colon Rectal Surg 2009;22:120-6.

5 Matsuoka H, Nakamura A, Iwamoto K, et al. Anorectal malignant melanoma: preoperative usefulness of magnetic resonance imaging. J Gastroenterol 2005; $40: 836-42$

Copyright 2021 BMJ Publishing Group. All rights reserved. For permission to reuse any of this content visit

https://www.bmj.com/company/products-services/rights-and-licensing/permissions/

BMJ Case Report Fellows may re-use this article for personal use and teaching without any further permission.

Become a Fellow of BMJ Case Reports today and you can:

- Submit as many cases as you like

- Enjoy fast sympathetic peer review and rapid publication of accepted articles

- Access all the published articles

Re-use any of the published material for personal use and teaching without further permission

Customer Service

If you have any further queries about your subscription, please contact our customer services team on +44 (0) 2071111105 or via email at support@bmj.com.

Visit casereports.bmj.com for more articles like this and to become a Fellow 